\title{
A!
}

This is an electronic reprint of the original article.

This reprint may differ from the original in pagination and typographic detail.

Barbieri, Donatella; Pantouvaki, Sofia

Cross-pollination and Shifting Research and Practice Trajectories; Expanding the Field in Costume Research

Published in:

Studies in Costume and Performance

DOI:

10.1386/scp.3.1.3_2

Published: 01/06/2018

Document Version

Peer reviewed version

Please cite the original version:

Barbieri, D., \& Pantouvaki, S. (2018). Cross-pollination and Shifting Research and Practice Trajectories;

Expanding the Field in Costume Research. Studies in Costume and Performance, 3(1), 3-10.

https://doi.org/10.1386/scp.3.1.3_2

This material is protected by copyright and other intellectual property rights, and duplication or sale of all or part of any of the repository collections is not permitted, except that material may be duplicated by you for your research use or educational purposes in electronic or print form. You must obtain permission for any other use. Electronic or print copies may not be offered, whether for sale or otherwise to anyone who is not an authorised user. 


\title{
EDITORIAL
}

\author{
DONATELLA BARBIERI \\ London College of Fashion, University of the Arts London \\ SOFIA PANTOUVAKI \\ Aalto University
}

\section{Cross-pollination and shifting research and practice trajectories: Expanding the field in costume research}

The connecting threads between the texts in issue 3.1 of Studies in Costume and Performance are not found solely through their content. They may be marked more productively by noting where their authors might situate themselves as researchers and practitioners in relation to costume. In this process, individual research and practice trajectories become evidenced, as also do points of connections and exchange between practice and research. From such an overview, an expanded view of costume emerges, which confirms its interdisciplinary and porous nature, one that presents with opportunities for further exchanges and research. Writing for this edition of Studies in Costume and Performance, scholars and researchers from a range of adjacent and overlapping disciplines enrich the field from their specific standpoints with insightful 
analysis, such as the ones provided by Alison Bancroft, from the perspective of fashion and psychoanalysis, and by Gamze Toylan, from that of media studies. A discursive intervention by dance researcher Mary Kate Connolly and fashion curation scholar Jeffrey Horsley on costumes' afterlives in the new Documents section - which will be introduced later - is followed by Deborah Nadoolman Landis's intervention, whose research journey, conversely, has led her from a film costume design practice to one in exhibition curation. Equally, costume design practitioners are included here as researchers authoring new studies, such as Elena Trencheva's on nation-building via early film costume, and Charlotte Østergaard on experimental self-masking practices. Many of the authors of reviews are designers who have been directing energy to develop practice-based research and scholarship, for example Sophie Jump, Eufrasio Lucena-Muñoz, Stephanie Mellini and Emily Collett, while others, Tiziana Ferrero-Regis, Sally Gray, Michelle Liu Carriger and Emily Brayshaw, situated within art, film, performance and fashion studies, are focused here on publishing around costume. Such cross-pollination between disciplines and practices presents costume as conversant with a widening range of discourses. At the same time, the engaging researchers, practitioners and scholars from a number of fields may also contribute to the advancement of those associated areas of research.

The structured presentations and research events centred on the study of costume that have been held over the last few years have facilitated the development of some of the texts included in this edition. For example, Landis' Documents intervention was edited from the transcript of her presentation at London College of Fashion (LCF) in 2012, part of the Paradigm Shift in Design for Performance through Costume series of lectures. Toylan presented research material as a lecture at Costume in Action, part of World Stage Design 2013 at Royal Welsh College of Music and Drama, while Trecheva's article was first presented as a paper at the Critical Costume conference in 2015 at Aalto University, and Østergaard's visual essay at the Costume and Fashion in Context and Practice symposium at Huddersfield University in 2016, and Bancroft's article was first discussed by the author at the launch of Studies in Costume and Performance in 2017, held at LCF. It is not by coincidence, therefore, that these voices may have come to the fore in our research publishing as the events listed above were all organized by the editors of this journal, which is dedicated to the advancement of research in costume, partly through the engagement with conversant fields.

Fashion scholar and author Alison Bancroft has written extensively on the work of Alexander McQueen and other fashion designers in relation to psychoanalysis (Bancroft 2012). In 'When the Chevalier d'Éon met Alexander McQueen: History, gender and subjectivity in the costumes in Eonnagata', she turns her attention to McQueen's only collaboration with performers via Ex Machina and its artistic director Robert Lepage who, with dancer Sylvie Guillem and choreographer Russell Maliphant, produced in 2009 at Sadler's Wells Theatre in London the dance piece Eonnogata that toured internationally until 2011. Eschewing purely historical and gender studies perspectives on the Chevalier d'Éon (1728-1810) whose story informs Eonnogata and who lived the last three decades of his life as a woman, Bancroft focuses her analysis of McQueen's designs on the indeterminacy of human subjectivity, the construction of the self and on the unconscious. Via her reading of Jacques Lacan's theories, which she applies to the costumed presentation of the performers' bodies onstage, what emerges is an addressing of a subjective incompleteness, 
of the edges of the body as imperfect boundaries of the self, in what ultimately reflects human experience and can be explored through the relationship between body and dress.

Gender studies and Judith Butler $(1988,1999,2004)$ are at the centre of Gamze Toylan's 'Subversion and reiteration of gender norms in television comedy through costume and performance: A study on The League of Gentlemen'. Toylan's analysis of the representation of the British TV comedy cross-dressed characters situates them within a significant tradition of costume-based contemporary performance practice, with precedents dating back to the late seventeenth century. Problematizing cross-dressing and parody in TV comedy, she brings to bear Mikhail Bakhtin's theories around the grotesque and carnivalesque body alongside notions of hyper-ugliness borrowed from art criticism. While considering the relationship between performer and costume as a fully enveloping body-mask, with the ever present, and comical, potential of slippages between layers, her analysis foregrounds a performer who can be entirely absorbed into the bodysuit costume to become 'other'. The article concludes on the ambiguity of cross-dressed characters, whose performance through costume reinforces, rather than subverts, gender norms.

Bakhtin (1984) is at the centre of Francesca Granata's Experimental Fashion: Performance Art, Carnival and The Grotesque Body (2016) reviewed by Sally Gray who relates both psychoanalysis and Butler to the grotesque in her reading of this publication. While numerous fashion practices are considered by Granata through the lens of the grotesque, Gray also draws attention to the intertwining of costuming and bodies in Leigh Bowery's 'birthing' performances, which, she notes, reflect his own gender instability. The unruly body is evidenced in the collaboration between Rei Kawakubo and Merce Cunningham, while the body modifying costuming of Lady Gaga's performances concludes both her review and the book.

In her study of 'Costume in early Finnish film (1921-31)', costume designer and researcher Elena Trencheva takes a historiographic approach to investigate the representation of national identity through costume in a period of nation-building for the then-newly-established Finnish nation. Trencheva dives into Finnish silent cinema and its costumes through the National Audiovisual Archive collection to study the surviving films, film and production stills, contextualizing them in relation to Finnish scholars' writing, providing the first study in English on the specific topic. With a background in a semiotic approach to film costume, Trencheva employs the concept of 'compositional motivation' deriving from Russian Formalist narrative theory, specifically by Tomashevsky ([1925] 2012), to analyse the functions of costume as a narrative tool for representing national identity. As she argues, this happens initially through conventional and idealized representations clearly indicating, for example social dichotomies (rural/urban) and associated values (high and low moral value), and later through transitional representations gradually encompassing contemporary dress elements, indicating the shift from a rural society to a modern, urban nation.

Documents, the new section inaugurated in this edition, is a space for the voices and the works of researchers and practitioners working directly with costume. These may capture developmental stages of processes, or reflections on specific details of the practice, or even elements of research that may provide starting points for further investigations. They may include aspects of conception, planning and production, experiments and new applications of existing knowledge, as well as reflections regarding specific features of exiting 
works by their authors. These could be presented as discursive exchanges between experts, as transcripts of public presentations, as selected aspects of the design processes, including pattern developments, textiles manipulation, digital interaction, physical experimentation; or could be framed as curatorial statements in relation to costume for performance, and could range from the analysis of historical objects to cutting edge contemporary practices and specific innovative discoveries through making.

Two Documents inaugurate this new section of the journal, both relating to the afterlife of the costume once the performance is over and to curatorial strategies that may advance knowledge around the expanding fields of costume for performance and of fashion curation. 'Objects of transformation' is a transcribed dialogue between exhibition maker Jeffrey Horsley and dance scholar Mary Kate Connolly on specific archived dance costumes that are part of their respective research trajectories. Horsley's costume-object of transformation is part of an exhibition devised through experimental and associative curatorial practices and Connolly's chosen archived costume becomes the impetus for a dance-making process, directed at proposing alternative approaches to curation, intended to reassess costume as critical to the archive of performance as much as to the dancer's body memory. Wider debates around exhibiting performed-in garments are captured in this dialogue, as costumes that are incomplete and damaged by repeated performances or that may be shop-bought and nonetheless associated with notable moments of dance creation come into focus.

'Character and costume in cinema: The Hollywood Costume exhibition', the second text in the Documents section, is by Deborah Nadoolman Landis, in which she vividly communicates the personal drive that drew her to costume curation and exhibition making in selected transcribed quotes from the public lecture that took place six months after the opening of the Hollywood Costume exhibition. Having previously designed several iconic films and intending to raise awareness of the complex and layered work of costume in character construction and storytelling, her motivation was also to address the substantial inequality in remuneration between set and costume designers. She goes on to describe the rationale for the exhibition, the reasoning that guided her objects selection and the thematic uses of space to foreground the multifaceted work of costume in film production. Particularly poignant was her finding of Dorothy's costume from The Wizard of Oz (1939) in the vaults of a bank in the City of London, and the insights gained by studying the internal seams of the dress, which evidence the costume designer's sophisticated use of appropriately skilled specialists to define place and time, not only through choices of fabrics but also through costume making processes in the intimate, hidden detailing of the construction. Landis's passionate defence of her practice remains relevant as does the need to improve the working conditions of costume workers (more on this later). Through the interaction with other conversant fields of research, including curation, as well as through the valuing its own specialist nature, costume design practice may indeed be praxis, intended to bring about active and positive change.

Artistic praxis, perceived here as a challenging of established costume design positions and processes, is the focus of the creative dialogue of Danish costume designer Charlotte Østergaard with her colleague, Jeppe Worning, through the experimental artistic research project MASK, presented in this issue as a visual essay. The two costume designers eliminate the mirror to explore mask and masking between the sensorial/experiential and the visual/ 
aesthetic. By becoming wearers, in addition to viewers, they develop a method for creating an embodied memory to enrich their design process, expanding the role of the designer/observer. Østergaard and her partner make a personal use of their material and the work of the one impacts on the work of the other. Their approach demonstrates openness and an insightful sharing of ideas materially, through co-creation via costume directly on the body. Their approach promotes a way of working with another designer, in a collaborative frame characterized by generosity, equality, and spontaneous and responsive inventiveness.

This issue of Studies in Costume and Performance includes a collection of exhibition and event reviews that demonstrate the richness and diversity of costume related events presented globally in the past year. Performance designer Sophie Jump reviews An Exhibition of Set and Costume Designs with drawings by Caspar Neher, the scenographer known primarily for his careerlong collaboration with Bertolt Brecht. The exhibition, presented in London, showed designs from three post-WWII opera productions designed by Neher, displayed together with select production photographs. In Jump's words, costume renderings are important parts of the performance-making process, allowing the costume designer to 'communicate to the director, performers and makers what is envisioned for the visual and spatial aspects of the production', but are not the final outcome. Exhibitions of costume drawings, therefore, open a window for the visitor into the designer's creative process and allow the investigation of the creator's intentions in detail through line, colour charts, inscriptions and fabric samples. ${ }^{1}$ As Jump notes, the exhibition on Caspar Neher's set and costume designs invites the visitor to understand aspects of Neher's process, and especially, 'how he balanced the aesthetic of his costume designs with practical necessity'.

The exhibition Costumi da Star (Costumes for Stars) was presented in Naples, Italy, showing iconic costumes by Italian costume designers such as Piero Tosi, Danilo Donati, Gabriella Pescucci, Milena Canonero, Carlo Poggioli and Alessandro Lai, produced by the leading Italian costume house Tirelli Costumes, which is globally celebrated for its influential contribution to costume making for theatre and film. Reviewed by Stephanie Mellini, it was curated by the C.E.O. of Tirelli Costumes, Dino Trappetti, in collaboration with a team of costume designers including Gabriella Pescucci. As defined by the exhibition's title, the display was arranged around costumes worn by celebrity actors, largely comprising of period costumes. With over twenty years' experience in costume making, Mellini observes the quality of Italian costume design and the skilled craftsmanship through a close examination of the costumes on display, which, as she remarks, give the impression that they'might have been the original period dresses of their time'.

The year 2017 also included a major international event for the field of performance design, the World Stage Design exhibition and festival, organized every four years since 2005 by the International Organisation of Scenographers, Theatre Architects and Technicians (OISTAT). Emily Collett reviews the exhibits by professional and emerging costume designers, which were part of the World Stage Design 2107 exhibition, which were selected through peer-review following an international call. Collett observes that the exhibition demonstrated the designers' ongoing interest in transforming the human body through costume as well as their materially driven approach, using both natural materials and traditional techniques as well as contemporary technology. Presented at the Kuandu Museum of Fine Arts at Taipei's
1. For another example of this type of exhibition, see Fiona Watt's review of the exhibition Drawing Theatre: Pamela Howard, in volume 2 issue 1 of this journal. 
National University of the Arts, this exhibition included the largest number of designers from Asia in the history of this or similar events.

Following, Emily Brayshaw provides a review of Million Dollar Mermaid, an exhibition on the pioneering Australian swimmer and performer Annette Kellerman featuring many of her costumes for her swimming performances, presented at the Museum of Applied Arts and Sciences (MAAS) in Sydney. The review puts to light the contextual frame that the exhibits provide on Kellerman's life and work, following Kellerman from her childhood swimming classes to becoming a champion swimmer and diver, performing underwater in mermaid acts, and eventually turning into a highly-paid star on the American Vaudeville as well as on film. Kellerman's understanding of how materials could transmit her connection with water, contributed to the development of women's swimwear and presented ideas for performance costumes that became iconic, such as the'mermaid costume'. Brayshaw captures Kellerman's spirit as a leading woman performer of the previous turn of century who used costume as a tool to develop her performance.

A more traditional type of costume exhibition was also hosted in Australia: it is The Costume Designer: Edith Head and Hollywood, presented at the Bendigo Art Gallery. This retrospective honoured the work of Edith Head, the longest serving costume designer in Hollywood history, through a display of film costumes and costume drawings from different US-based collections. In her review, Ferrero-Regis points to the use of dress forms for the display of the costumes as a choice that indicates the value embedded in the making of a costume as well as the importance in the costume designer's work, presented in an art gallery as an 'individual artist'. The author observes the juxtaposition between the three-dimensional costumes and the black and white film stills used in the background behind the costumes, bringing the objects close to the context of the films to which they belong and to the image of the actor wearing it. Head's work is framed within the Studio System during Hollywood's Golden Age, to which - in Ferrero-Regis' words - Head 'fitted perfectly' as an excellent collaborator.

Two exhibitions presented on the other side of the Pacific, both in Los Angeles, are also reviewed in this issue, reflecting the diversity of costumed performance practices. Michelle Liu Carriger provides a review of the 11th Annual Emmy Costume Exhibition at FIDM, one of the few regular exhibitions focusing on television costume. It has been hosted at FIDM Museum \& Galleries annually since 2006 and presents costume design in television series and programmes on television network, cable and Internet streaming. Carriger offers commentary on two main themes. First, on the experience of the 1:1 scale of the costumes, displayed outside the screen and in close proximity to the visitor, and the observations that this display evokes in relation to the form of the costume, the absent actors' bodies and the creation of silhouettes. Secondly, the author remarks that costume can be self-referential in relation to already well-known characters as well as to pre-existing iconic costumes.

In the second half of 2017, the Los Angeles County Museum of Art (LACMA) presented the exhibition Chagall: Fantasies for the Stage, which examined a lesser-known period and area of activity of the celebrated Russian painter Marc Chagall: his work in ballet and opera in mid-twentieth century. In her review, Caroline Hamilton highlights the variety and richness of the techniques used in the costumes (painting, large-scale construction and layering of fabrics), some of which are hand-painted by Chagall himself, turning 
the costumes from working garments to works of art in their own right. The author's conclusion points out the importance of dance costume as a document of the dance performance and the individual artists related to it.

This issue concludes with a review of the 3rd Symposium on Theatre Arts themed 'Costume on Stage', which took place in Madrid in June 2017. The scenographer Eufrasio Lucena-Muñoz delivers a review that not only depicts the specific event offering the reader a detailed account, but also provides the context of the current landscape of Spanish costume design, including insights on collaboration practices between designers, technicians and institutions, as well as designers' critical concerns and discussion themes. Moreover, Lucena-Muñoz provides links to all the recordings of the talks, presentations and discussions, made available online by the organisers, Centro Dramático Nacional and AAPEE. The review of this event opens a window for our international readership towards the not-frequently internationally represented professional community of Spanish designers.

Events such as this, locally as much as internationally, are beginning to challenge the lack of representation, recognition and understanding of costume. By platforming and foregrounding practitioners and researchers, they enable and affirm a multiplicity of voices within a developing community of researchers, intent on questioning not only their practice but also the status quo. Articulating the significance and the work of costume and its complex relationships with interconnected fields may also eventually begin to operate on concerns around working conditions, as articulated not only by Landis but also, more recently, by CITA Costume in Theatre Association. ${ }^{2}$

Research around costume therefore does not purely inform a more advanced level of thought. It is also about thought translating into awareness and respect of specialisms, to give value to the work of designers, makers, artists and all who collaborate in the productions of costume for performance. While reaffirming the reasons emphasized by Bancroft, that the costumed body onstage offers a greater understanding of human existence, giving value to research in costume may also help further the cause of fairer conditions and pay for costume workers. By articulating and developing knowledge in the dialogue between practice and theory and by expanding the field beyond its existing boundaries, this journal serves a range of roles in developing awareness, knowledge and values around costume research.

We paraphrase the outgoing editor Kate Dorney (2017) who, in her editorial for issue 2.2 expressed the wish that it may possible, at some point in future, for it not to be necessary to begin or end every editorial with a reminder of what we are doing and why. That point may not yet have been reached as much still needs to be done. Research publishing on costume remains urgent, compelling and critical, a notion that continues to energize editors, authors and the board of this journal. Having been co-opted into our team as expert journal editor to support the establishing of Studies in Costume and Performance, Kate Dorney now feels she has done her job and has left to focus entirely on the other journal that she edits. In her place, our new co-Editor will be Suzanne Osmond from the National Institute of Dramatic Arts, Sydney, Australia.

We warmly welcome Suzanne, who has been our book reviews editor since the first issue of the journal. We are delighted that she has joined our team of journal editors and she is currently in the process of editing 3.2, due out in November 2018. We are also very happy to welcome our new book reviews editor, Patricia Lennox from New York University Gallatin who has
2. CITA Survey of costume workers' pay, which took place in 2016, identified that 93 per cent of the respondents were female and that 41 per cent of the respondents earned less than £9.20 per hour, with 19 per cent earning less than the UK minimum wage of £7.20 per hour 
co-edited Shakespeare and Costume (Bloomsbury, 2015). Kate Dorney will join our Editorial Board from where she will be able to continue to encourage the development of Studies in Costume and Performance. Our growing readership confirms the value of our work and may, we hope, also include future authors to whom we extend the invitation to submit research for publishing, to contribute their expert knowledge as reviewers and their articulation of ideas and processes for our visual essays and new Documents section. With the continued engagement of the overlapping communities of costume scholarship, practice and praxis, and the many communities of research with which they interact, the ongoing advancement of discourse both anticipates and maps an ever-expanding field of research.

\section{REFERENCES}

Bakhtin, Mikhail (1984), Rabelais and His World (trans. H. Iswolsky), Bloomington, IN: Indiana University Press.

Bancroft, Alison (2012), Fashion and Psychoanalysis: Styling the Self, London and New York: I.B. Tauris.

Butler, Judith (1988), 'Performative acts and gender constitution: An essay in phenomenology and feminist theory', Theatre Journal, 49:1, pp. 519-31.

- (1999), Gender Trouble: Feminism and the Subversion of Identity, New York and London: Routledge.

- (2004), Undoing Gender, New York and London: Routledge.

CITA (2016), 'CITA pay survey', YouTube, https://www.youtube.com/ watch?v=wJ5HnvX4YqM. Accessed 25 February 2018.

Tomashevsky, Boris ([1925] 2012), 'Thematics', in L. T. Lemon and M. Reis (eds), Russian Formalist Criticism: Four Essays, 2nd ed., Lincoln and London: University of Nebraska Press, pp. 61-98.

Watt, Fiona (2017), 'Drawing theatre: Pamela Howard - an exhibition in the crab studio at arts university Bournemouth, curated by Rebecca pride and co-curated by Sam Edwards, 22 March - 22 April 2016', Studies in Costume and Performance, 2:1, pp. 88-90.

Donatella Barbieri and Sofia Pantouvaki have asserted their rights under the Copyright, Designs and Patents Act, 1988, to be identified as the authors of this work in the format that was submitted to Intellect Ltd. 